\title{
The mystery of a carpenter's headache
}

\author{
Sabiha Ali, ${ }^{1}$ Krishnaraj Sinhji Rathod, ${ }^{2}$ Immaneni Viswanath ${ }^{1}$
}

${ }^{1}$ University Hospital NHS Trust, Barking Havering Redbridge, Ilford, Essex, UK

${ }^{2}$ Department of Cardiology, Barking Havering Redbridge University Hospital NHS Trust, Ilford, Essex, UK

\section{Correspondence to}

Dr Krishnaraj Sinhii Rathod, krishnarajrathod@gmail.com

\section{(1) \\ CrossMark}

To cite: Ali S, Rathod KS, Viswanath I. BMJ Case Rep Published online: [please include Day Month Year] doi:10.1136/bcr-2013202349

\section{DESCRIPTION}

We present an intriguing case of extensive intracranial venous sinus thrombosis.

A 41-year-old Romanian carpenter presented to the accident and emergency department in the early hours of the morning with a severe occipital headache.

The patient reported the headache to be of sudden onset associated with progressive neck stiffness and photophobia. The severity of the headache had increased after an episode of coughing. There appeared to be no history of viral or coryzal symptoms, nor that of any related trauma. On examination the patient exhibited a complex ophthalmoplegia. He had no significant drug history or medical history including venous thromboembolic disease. An initial non-contrast CT head revealed extensive intracranial sinus thrombosis (figure 1). This was further confirmed with a CT venogram. A clotting, vasculitic and infection screen returned all normal.

The patient was transferred over to the neurology team who decided to start heparin followed by long-term warfarin therapy. He continued to improve clinically over 3 weeks and was discharged home with outpatient follow-up.

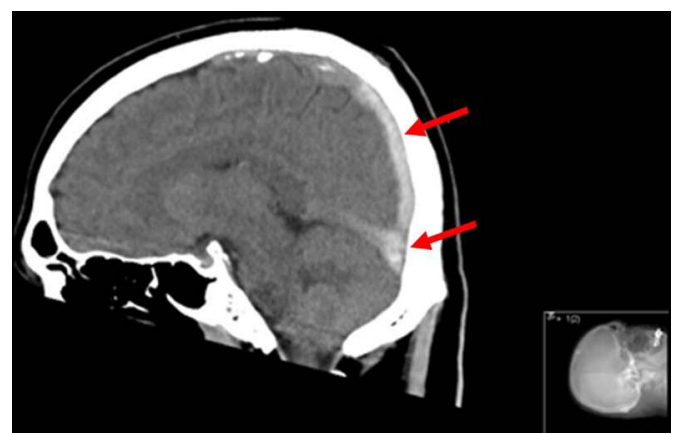

Figure 1 The red arrows displayed on this sagittal image show multiple hyperdense areas in keeping with extensive intracranial venous sinus thrombosis.
The underlying aetiology of this case remains unclear.

Intracranial venous sinus thrombosis has been reported to be a consequence of infections to the orbit, ears, paranasal sinuses and trauma. ${ }^{1}$ Complex ophthalmoplegia is due to involvement of the third, fourth and sixth cranial nerves as they are attached to the lateral wall of the cavernous sinus. If clinically indicated, the role of starting antibiotics early is important. ${ }^{2}$ The main differentials would be stroke, subarachnoid haemorrhage, epidural and subdural infections and orbital cellulitis.

\section{Learning points}

- Intracranial venous sinus thrombosis should be considered in any patient presenting with a headache with associated cranial nerve findings.

- Prompt administration of antibiotics in ear, nose and throat infections in the context of suspected intracranial venous sinus thrombosis is important.

- CT imaging and venography are useful tools for confirming the diagnosis of intracranial venous sinus thrombosis.

- There is a role for the administration of anticoagulation in intracranial venous sinus thrombosis.

\section{Competing interests None.}

Patient consent Obtained.

Provenance and peer review Not commissioned; externally pee reviewed.

\section{REFERENCES}

1 Sharma R. Cavernous sinus thrombosi. Medscape, Mar 2013. http://misc.medscape.com/pi/android/medscapeapp/html/A791704business.html (accessed 10 Mar 2013).

2 Clifford-Jones RE, Ellis CJ, Stevens JM, et al. Cavernous sinus thrombosis. J Neurol Neurosurg Psychiatry 1982:45:1092-7.

Copyright 2013 BMJ Publishing Group. All rights reserved. For permission to reuse any of this content visit http://group.bmj.com/group/rights-licensing/permissions.

BMJ Case Report Fellows may re-use this article for personal use and teaching without any further permission.

Become a Fellow of BMJ Case Reports today and you can:

- Submit as many cases as you like

- Enjoy fast sympathetic peer review and rapid publication of accepted articles

- Access all the published articles

- Re-use any of the published material for personal use and teaching without further permission

For information on Institutional Fellowships contact consortiasales@bmjgroup.com

Visit casereports.bmj.com for more articles like this and to become a Fellow 